How does creative self-efficacy influence employee well-being? Exploring the moderating role of transformational leadership

Öcel, Hatem

KarabukUniversity, Turkey (hatemocel@hotmail.com)

Received: 17 December 2015

Revised: 18 February 2016

Available Online: 23 February 2016

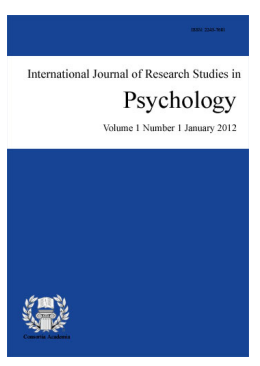

ISSN: 2243-7681 Online ISSN: 2243-769X

Accepted: 20 February 2016

OPEN ACCESS

\title{
Abstract
}

The present study examined the relationships among creative self-efficacy, well-being as well as the moderating effect of transformational leadership. Participants were 272 employees who have different professions from different companies both public and private sector. The moderated regression analysis revealed positive relationships between creative self-efficacy, transformational leadership and well-being. According to results of this study employees with a high level of creative self-efficacy demonstrate a high level of well-being at work, and transformational leadership plays a moderating role. When employees' creative self-efficacy is high, those with transformational leader exhibit greater well-being at work.

Keywords: creative self-efficacy; transformational leadership; well-being 


\section{How does creative self-efficacy influence employee well-being? Exploring the moderating role of transformational leadership}

\section{Introduction}

Employee well-being is one of the most important research topics among the psychologists who are working on organizational psychology. Factors in the workplace can seriously affect the individual's well-being and mental health (Danna \& Griffin, 1999). Organizational psychologists have examined a wide variety of individual and organizational variables that influence well-being. In this context self-efficacy (Siu, Lu, \& Spector, 2007) and leadership (van Dierendonck, Haynes, Borrill, \& Stride, 2004) have been studied for several decades. In particular, transformational leadership (TL) styles have been positively linked to well-being (Nielsen \& Munir, 2009). House (1981) assumed that other people at work, particularly one's supervisor, can affect the way one feels about one's work and about oneself. Researchers converge on the point that subordinates are influenced by the support received from their supervisor (Offermann \& Hellmann, 1996; Sosik \& Godshalk, 2000). According to Gist and Mitchell (1992), self-efficacy is related with contextual factors, such as leadership behaviour as well as personal factors. The purpose of this paper is to investigate whether transformational leadership moderates the effects of having creative self-efficacy on well-being. Transformational leadership develops the confidence of employees in their abilities that helps them move further. Therefore, individuals' well-being will be higher if they are high (versus low) in creative self-efficacy and when they come under the influence of transformational leaders. Although there are some studies about relationships between self-efficacy (Priesack \& Alcock, 2015; Siu, Lu, \& Spector, 2007) and creativity (Dolan \& Metcalfe, 2012; Singh \& Tung, 2015) with well-being respectively, there is no study about how creative self-efficacy has an effect on well-being. Furthermore, there is a paucity of research concerning the mediating or moderating role of TL in countries with non-Western and different cultural background such as Turkey.

\section{Review of the Literature}

\subsection{Review of the literature on well-being}

Well-being is multi-faced structure, and has been used in different ways, including different dimensions and degrees of scope. Diener (2000) claimed that "SWB refers to people's evaluations of their lives -evaluations that both are affective and cognitive. People experience abundant SWB when they feel many pleasant and few unpleasant emotions, when they are engaged in interesting activities, when they experience many pleasures and few pains, and when they are satisfied with their lives. There are additional features of a valuable life and of mental health, but the field of SWB focuses on people's own evaluations of their lives." Cognitive evaluation includes individual', cognitive judgement, about life satisfaction, whereas affective evaluation includes enjoying the most positive affect and the least negative affect (Eid \& Larson, 2008).

Diener (2000) asserts that people's moods and emotions reflect on-line reactions to facts happening in their life. Every single person makes broader judgements about his or her life at large including marriage and work. SWB has several separable components: satisfaction about life (global judgements about one's life), satisfaction with important domains (satisfaction with work), positive affect (encountering many nice emotions and moods), and low levels of negative affect (encountering few unpleasant emotions and moods).

The fact is that everyone agrees that employee well-being is an important issue for both employees and employers, not only because of the happy/productive employee thesis (Wright \& Staw, 1999), but also because strain in the workplace produce negative consequences for employees, such as frustration, depression, anxiety, and many physical problems, including cardiovascular disease and high blood pressure among individuals (e.g. 
Siu, Lu, \& Spector, 2007). Ryff (1995) defines psychological well-being as "make an effort for excellent on account of prove true potentials of individual". Based on this view, well-being is the endeavor for improvement and excellence that prosper in inception of individual potentials and capability.

There are a number of empirical studies suggesting that creativity is one of the relevant variables with subjective well-being (Collins, 2006; McLellan, Galton, Steward, \& Page, 2012). Collins (2006) proposed that positive affect, physical health, psychological adjustment and vivacity predicts by creativity. Greaves and Farbus's (2006) study also supports the view that creative activities increase well-being and lead to positive changes in elderly health. The research results showed that self-efficacy is another variable which is closely related to the well-being (Bhupinder \& Rakhi, 2009; Datu, 2013; Priesack \& Alcock, 2015; Souza, Torres, Barbosa, Lima, \& Souza, 2014). Bandura points out that self-efficacy belief has an impact on emotional experiences (Bandura, 1997). In this case when people have low self-efficacy, they may believe that incidents and accidents are harder than what they really are, and presumably this will increase their stress and anxiety level. In contrast people with high self-efficacy this will lead to the regulation of the stress process, to higher self-esteem, better well-being, better physical conditions (Bandura, 1997; Bisschop, Knegsman, Beekman, \& Deeg, 2004; Tamannaeifar \& Motaghedifard, 2014).

\subsection{Review of the literature on creative self-efficacy}

General self-efficacy is defined as a personal judgement of how well one carries out the necessary course of action in dealing with a potential case (Bandura, 1982). Bandura stated that strong self-efficacy is an important requirement for creative productivity and the discover of "new knowledge." This is because self-efficacy has an effect on the motivation and ability to engage in specific behavior (Bandura, 1977); the concept of self-efficacy also provide help for understanding creative action in organizational settings.

Cervone and Peake (1986) stress that people with high self-efficacy are more efficient in their actions, which results from their confidence in their ability to control situations and to handle problems. The employees who have high level of creative self-efficacy are able to overcome when they are faced with a challenge task in their daily basis work conditions. Besides perceived creative self-efficacy concerns people's belief in their ability to perform in ways that give them control over events that affect their lives.

Many of the studies about well-being and self-efficacy focus on general self-efficacy rather than creative self-efficacy in the organizational psychology literature. But studies showed that creativity also has a positive impact on personal well-being. Research has been conducted by Greaves and Farbus (2006) exposed that encouraging creativity is more likely to positively affect health and well-being. Although the studies mentioned above provide a foundation for further exploration of creativity and self-efficacy, they don't provide evidence as to how transformational leadership moderate the relationship between creative self-efficacy and well-being through. Building on this discussion, it seems quite possible that a relationship exists between creative self-efficacy and well-being. Although the positive effects of transformational leadership on well-being have been established in many research context, (Kelloway, Turner, Barling, \& Loughlin, 2012; Liu, Siu, \& Shi, 2010; Nielsen \& Munir, 2009), present study aims at understanding whether transformational leadership moderates the effect of creative self-efficacy on well-being.

\subsection{Review of the literature on transformational leadership}

Transformational leadership is based on a strong identification with the leader and the environment where the leadership takes place. Within this framework leader promotes follower awareness, understands moral values and inspires visions, and encourages followers transcend their own personal goals and interest for the collective good (Bass, 1998, Bass \& Riggio, 2006). Transformational leadership consists of four components. These include: 1) idealized influence -the leader acts as a role model and takes the lead in displaying desirable behavior, 2) inspirational motivation -the leader outlines a clear vision and the way forward, 3) intellectual stimulation -the 
leader encourages followers to make their own decisions, both creative and innovative, and 4) individualized consideration -the leader acts as a coach and mentor, considering followers' individual needs, and capabilities (Bass, 1985; Bass \& Riggio, 2006).

In these days, attention has been directed toward how transformational leaders may shape followers' perceptions of their working conditions and subjective well-being. Skakon et al. (2010) found that transformational leadership was positively related to affective well-being and negatively related to burnout and stress (Skakon, Nielsen, Borg, \& Guzman, 2010). As suggested by Gilbreath and Benson, (2004) employee well-being is affected both by the physical work environment and the psychosocial work environment. Sparks, Faragher, and Cooper (2001) pointed out that management style has been seen as one of the main psychosocial work environment issues in point of employee well-being and occupational health in the last century. That is because leaders could have a great impact on followers' work lives both positively-negatively, leaders have been the focus of attention (e.g. Gilbreath \& Benson, 2004; Harris \& Kacmar, 2006).

Gilbreath and Benson (2004) also pointed out that many leadership behaviours were related to psychological well-being in the same study. These behaviours included encouraging employees to make independent decisions, acknowledging employees and showing consideration and concern for them. It has been asserted that transformational leadership has the ability to elevate followers and increase positive affective well-being. It is possible that through individualized consideration which is one of the components of transformational leadership, leaders show concern for their employees through listening and being compassionate (Sivanathan et al., 2004). Thereby, employees who work with such a kind of leader will feel comfortable and well thanks to their creative self-efficacy belief. Sivanathan et al. (2004) stressed that through the intellectual stimulation characteristics of the transformational leadership, followers will feel free to make their own decisions and be creative and innovative in their work. Thus, it is going to be feasible to be psychologically well when they use creative ways by self-efficacy in their jobs.

Notable studies point to the higher levels of transformational leadership being related to higher well-being (Arnold, Turner, Barling, Kelloway, \& McKee, 2007; Nielsen, Randall, Yarker, \& Brenner, 2008; Stenling \& Tafvelin, 2014). Prior studies demonstrated the direct or mediated effects of transformational leadership on well-being (Nielsen \& Daniels, 2012; Sivanathan et al., 2004; Skakon et al., 2010), but this study focuses on its moderating role. Individuals with a high level of creative self-efficacy and working with a leader who has a transformational manner are successfully able to cope with many difficulties at work because they have greater confidence and cognitive flexibility. Hence, employees with high level of creative self-efficacy will have a higher level of well-being when they work with transformational leader. Consequently, the hypothesis of the present study was to investigate whether the transformational leadership moderates the relationship between creative self-efficacy and well-being.

\section{Method}

\subsection{Participants}

The data were collected from full-time personnel in a Turkish public and private sector organization. Questionnaires were distributed to 350 non-managerial employees and a total of 272 usable surveys (77\% response rate) were returned. Paper-based questionnaires inquired about respondents' perceptions regarding their creative self-efficacy, transformational leadership and well-being. All questionnaires distributed during regular work hours at the each work place. The most important selection criteria for participants was being fulltime worker. The average age of the 272 respondents was 35.6 years (SD 8.8), $61 \%$ had a bachelor's degree, and age ranged from 20 to 62 years. The majority of the sample was male (54.8\%) and worked in the public sector $(88.2 \%)$. The participants' work period range from 1 to 33 years. 


\subsection{Instruments}

The hypothesis of the study was tested using scales which will be discussed below, based on data from a sample of employees from several organizations both public and private sector. The instruments employed are described below. Within the well-being literature, there is an extensive and diverse range of instruments for the measurement of well-being. A reliable and valid well-being scale was selected. The well-being scale and other scales in the present study were originally designed in English and then translated into Turkish by two scholars competent in both languages. To avoid cultural bias and to ensure validity, the Turkish version was translated back into English by a language professional, and special attention was paid in order to avoid potential misunderstandings due to translation.

Well-Being - Respondents' perceived level of personal well-being was assessed using the Satisfaction with Life Scale, developed by Diener, Emmons, Larsen, and Griffin (1985). This 5-item scale is among the most widely used measures in psychology to assess global life satisfaction, showing high levels of internal consistency and temporal reliability (Pavot, Diener, Colvin, \& Sandvik, 1991). Respondents were asked to rate their level of agreement using a 6-point scale ranging from 1 (strongly disagree) to 6 (strongly agree). A sample item is "In most ways my life is close to my ideal". Turkish adaptation of the Satisfaction with Life Scale was carried out by Yetim (1993) and Cronbach alpha of the scale was .86. The alpha coefficient of this scale was .94 for the present study.

Creative Self-Efficacy - Creative self-efficacy was measured using a questionnaire, developed by Tierney and Farmer (2002), which included statements about perceived efficacy in producing ideas, solving problems, and in elaborating or improving upon others' ideas. A sample item is "I have confidence in my ability to solve problems creatively". The response scale ranged from 1 (very strongly disagree) to 7 (very strongly agree) whereby a higher score indicated a higher creative self-efficacy beliefs. The items were adapted to Turkish by the author and alpha coefficient was found to be .92 .

Transformational Leadership - Transformational leadership behavior was measured using 37 items adapted from the Multifactor Leadership Questionnaire (MLQ) form 5X (Bass \& Avolio, 1990). For each item, respondents were required to rate the transformational leadership behavior of their immediate supervisor using a five-point Likert scale ( $1=$ 'Not at all' and $5=$ 'Very frequently, if not always'). Sample items for each of the four dimensions of transformational leadership include: (a) Idealized Influence, "Emphasizes the importance of having a collective sense of mission"; (b) Inspirational Motivation, "Articulates a compelling vision of the future"; (c) Intellectual Stimulation, "Suggests new ways of looking at how to complete assignments"; and (d) Individual Consideration, "Spends time teaching and coaching." Consistent with previous empirical work (Avolio, Gardner, Walumbwa, Luthans, \& May, 2004; Kark, Shamir, \& Chen, 2003; Liu, Zhu, \& Yang, 2010; Zhu, Newman, Miao, \& Hooke, 2013) the four sub-components of transformational leadership (idealized influence, inspirational motivation, intellectual stimulation and individualized consideration) were combined into a single, higher-order factor. One other prior research (Judge \& Bono, 2000) also validated the use of a single scale to represent transformational leadership.

Turkish adaptation of the scale was carried the author and alpha coefficient of the scale was .99 for this study. A confirmatory factorial analysis was performed, using LISREL (Jöreskog, \& Sörbom, 2001) in order to test the factorial structure of Multifactor Leadership Questionnaire Maximum likelihood methods estimation were used. Fit index methods: $X^{2}$, AGFI (adjusted goodness of fit index), GFI (goodness of fit index) and RMSEA (Root Mean Square Error Approximation) were used. $X^{2}$ proves the difference between observed and predicted covariance matrix. The fit indices of the one factor model were satisfactory: $X^{2} / d f: .45$, RMSEA was .00, $\mathrm{GFI}=1.00$, and AGFI $=1.00$, Chi-Square $=278.15, \mathrm{df}=623, \mathrm{P}$-value=1.00000, RMSEA=0.000. For all that fit indices of the four factor model were worse: $X^{2}=3182.75, d f=623, X^{2} / d f: 5.10$, P-value $=0.00000$, RMSEA=0.123, $\mathrm{GFI}=.61, \mathrm{AGFI}=.56$. 
Öcel, H.

Control Variables - In addition to the substantive measures described above, several control measures were included using data from the organization's human resource records. Because prior research has suggested that employee age, education level, gender, and company tenure may have potential influences on employee creative behavior (Farmer et al., 2003; Gong et al., 2009; Shin \& Zhou, 2003; Tierney \& Farmer, 2011), these four variables were included as control variables.

\section{Results}

Table 1 presents the correlations, means, standard deviations, and internal consistency statistics (Cronbach's alpha) for the study variables. All reliability statistics showed a fair to good internal consistency. The data were analyzed using hierarchical regression analysis.

Table 1

Means, Standard Deviations, and Internal Consistencies, and Correlations

\begin{tabular}{llllllllll}
\hline Subscale & M & SD & 1 & 2 & 3 & 4 & 5 & 6 & 7 \\
\hline 1)Age & 35.60 & 8.86 & -- & & & & & & \\
2)Gender & & & $.22^{* *}$ & -- & & & & & \\
3)Education & 2.90 & .64 & -.02 & .06 & -- & & & & \\
4)Tenure & 6.87 & 7.00 & $.67 * *$ & $.16^{* *}$ & .03 & -- & & & \\
5)Creative Self Efficacy & 50.79 & 8.34 & .02 & -.07 & .14 & .10 & $(.92)$ & & \\
6)Trans. Leadership & 123.38 & 43.03 & .05 & .00 & .12 & -.02 & $.11^{*}$ & $(.99)$ & \\
7)Well-Being & 21.56 & 8.18 & .11 & -.14 & .17 & .09 & $.25^{* *}$ & $.57^{* *}$ & $(.94)$
\end{tabular}

Note. $\mathrm{N}=272$. Trans. Leadership=Transformational Leadership. The numbers in parentheses on the diagonal are Cronbach's alphas. $* * p<0.01 ; * p<0.05$

Preliminary investigation of the data showed that this data set were normally distributed. The hypothesis was tested using hierarchical regression analysis (Table 2). In step one subject variables were introduced and education level $(\beta=.18, p<.00)$ along with gender correlated with well-being $(\beta=.18, p<.01)$. In step two creative self-efficacy was introduced and was found to significantly correlate with employees' well-being $(\beta=.16$, $p<.01)$. In step three, transformational leadership was introduced and it was found to be associated with employees' well-being $(\beta=.55, p<.01)$.

The moderating relationship refers to situations in which the relationship between a predictor (creative self-efficacy) and outcome variable (well-being) changes as a function of the level of the moderator (transformational leadership). The interaction terms were entered in step 3 and the interaction term was significantly associated with well-being $(\beta=.73, p<.01)$, indicating that transformational leadership moderated the relationship between creative self-efficacy and employee well-being. Thus, research hypothesis was supported.

Table 2

Moderated Regression Analyses for Well-Being

\begin{tabular}{|c|c|c|c|c|c|c|c|}
\hline Variables & $\mathrm{B}$ & $\beta$ & $t$ & $p$ & $R^{2}$ & Adjusted $R^{2}$ & $F_{\text {chan. }}$ \\
\hline Step 1 & & & & & .07 & .06 & 7.28 \\
\hline Age & .11 & .12 & 1.53 & .12 & & & \\
\hline Gender & -2.96 & -.18 & -2.93 & .00 & & & \\
\hline Education & 2.36 & .18 & 3.15 & .00 & & & \\
\hline Tenure & .04 & .03 & .46 & .64 & & & \\
\hline Step 2 & & & & & .40 & .38 & 34.28 \\
\hline Creat. Self. Eff. & .16 & .16 & 3.42 & .00 & & & \\
\hline Trans. Lead. & .10 & .55 & 11.29 & .00 & & & \\
\hline Step 3 & & & & & .41 & .40 & 30.05 \\
\hline $\begin{array}{l}\text { Creat. Self. Eff. x Trans. } \\
\text { Lead }\end{array}$ & .003 & .73 & 2.39 & .01 & & & \\
\hline
\end{tabular}


In order to examine the nature of the interaction effect displayed in Figure 1, following Aiken and West (1991), participants were divided into two groups according transformational leadership scores; participants who scored $1 \mathrm{SD}$ or more below the mean transformational leadership scores and participants who scored 1 SD or more above the mean transformational leadership scores. An analysis of simple slopes revealed a positive relationship between creative self-efficacy and employees' well-being when transformational leadership is high and a less positive relationship when transformational leadership is low.

\section{Discussion}

The purpose of this paper was to investigate whether transformational leadership moderates the effects of creative self-efficacy on well-being. These results extend findings from previous research and contribute to the understanding of the creative self-efficacy affects well-being. In establishing transformational leadership as a moderator between creative self-efficacy and well-being, it has been addressed a moderator previously unexamined. In conclusion, this study has found a merely positive relationship between creative self-efficacy and well-being that was moderated by the transformational leadership. Previous studies have reported a relationships between transformational leadership and well-being (Arnold, Turner, Barling, Kelloway, \& McKee, 2007; Bono \& Ilies, 2006; Nielsen \& Daniels, 2012; Nielsen \& Munir, 2009; Stenling \& Tafvelin, 2014), and it has been confirmed in this analyses. Bono and Ilies (2006) suggest that charismatic leaders express positive emotions, which are transferred to followers, resulting in the experience of positive mood by followers.

Employees who have high level of creative self-efficacy will have confidence about their actions and this will enable them to find solutions for problematic situations as well as feeling self-confident (Cervone \& Peake, 1986). Therefore, employees who have positive affectivity when faced supportive behaviors of their leaders leads for feel well psychologically.

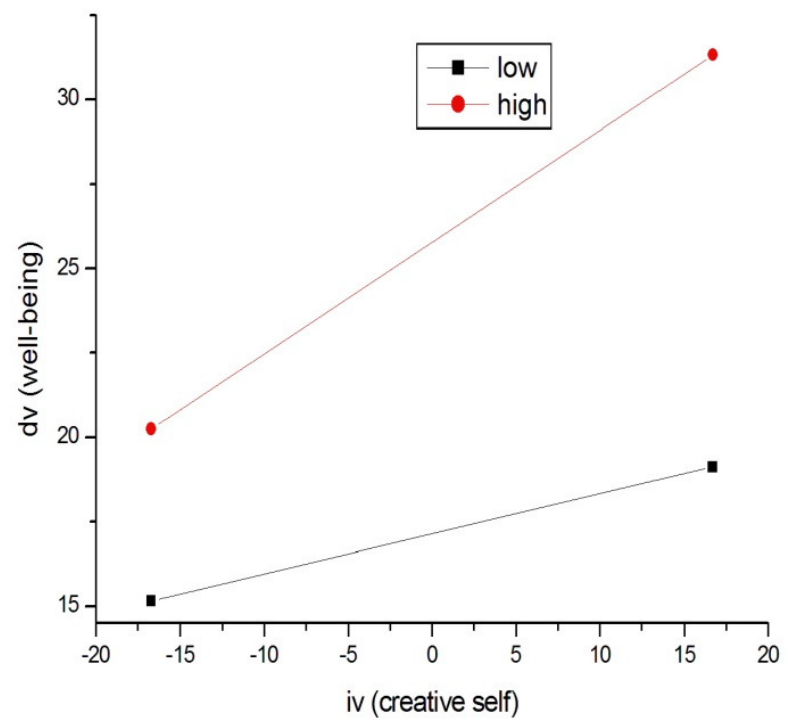

Figure 1. Interaction of creative self-efficacy and transformational leadership on well-being

Creative self-efficacy is the belief in one's capacity to successfully put into action novelties or existing resolutions (Tierney and Farmer, 2002, 2011). Hence, it is reasonable to think that creative self-efficacy can also play a role in feeling psychologically well. Being personally efficient and thinking or acting creatively on the job or about problems based on employee work life is a significant. In short, those employees with higher creative self-efficacy are going to feel psychologically well. Employees with a high level of creative self-efficacy demonstrate a high level of well-being at work; that is, creative self-efficacy is an effective predictor of well-being as examined in this study.

It was expected that creative self-efficacy has positive impact on well-being when transformational leadership is strong. Overall, this study contributes to the literature as to how transformational leadership 
Öcel, H.

moderates relationship between creative self-efficacy and psychological well-being. Those with a high creative self-efficacy will find creative solutions to solve a problem more easily when they have difficulties during their work hours and thus their well-being will not be damaged. The results of this study also add to a more comprehensive understanding of creative self-efficacy as it relates to employee well-being.

Cultural differences would be particularly important to transformational leadership. Critical leadership style is seen as something negative by employees and it leads to some negative emotions or self-dissatisfaction about himself/herself by employees in Turkish cultural context. However, being in a supportive attitudes and less critical as a leader is considered as more desired attitude by the staff and leads to positive emotions. In conclusion, cultural differences should be considered as another explanation frame for the results of present study alongside theoretical explanations about effects of transformational leadership on well-being.

\subsection{Implications and Limitations}

The results of this study make some theoretical and practical implications for employees and employers. First of all, it shows that positive relationship between creative self-efficacy and employee well-being. Results also point out that to work with supportive leaders for employees whom have a high level of creative self-efficacy contributes to greater well-being on the part of them. When managers or leaders let employees to be creative doing their job it makes employees feel better in psychologically. Having high level of psychological well-being might help to employees about to cope with the problems encountered at work and family-work conflicts.

Despite the contributions of this study, it is not without limitations. First, the research design applied in this study is cross-sectional, making it difficult to draw confident causal conclusions. This issue should be further investigated within longitudinal and experimental designs, which are clearly needed in this area to increase our knowledge. Second, all variables were assessed through self-report measures and may therefore be influenced by common method bias (Podsakoff, Mackenzie, Lee, \& Podsakoff, 2003). It is known that self-report measures are susceptible to various biases. Two methods have been used to minimize such bias, both in data collection and data analyses. First, respondent confidentiality was ensured. Second, questionnaire items were counterbalanced such that it was not clear to the respondents which items belonged to which scales. It could also be argued that it may have been favorable to study the objective measure of transformational leadership; however, the present study dealt with the perceptions of followers rather than an objective measure of transformational leadership behaviors. These potential rating biases could be reduced in future research whereby collecting data from different sources by different methods. Future research that intends to tests validity of present results should overcome these limitations. For instance, future research should use objective measures of employee well-being outcomes, such as recorded sick days or functional prognostication instead of well-being questionnaire or both. Finally, research results were obtained from one country only in Turkey which is considering as a collectivistic culture. Future research should replicate these findings in both other collectivist as well as individualistic cultures.

Despite all these limitations, the present study was still able to demonstrate a significant association between creative self-efficacy, transformational leadership and well-being. Based on this finding, we can assume that working with supportive leaders and having high level of creative self-efficacy contribute to greater well-being on the part of employees.

Acknowledgements: This study has been presented as an oral presentation at the 17th EAWOP congress in Oslo, 20th - 23rd of May 2015. 


\section{References}

Aiken, L. S., \& West, S. G. (1991). Multiple regression: Testing and interpreting interactions. Newbury Park, CA: Sage.

Arnold, K. A., Turner, N., Barling, J., Kelloway, E. K., \& McKee, M. C. (2007). Transformational leadership and psychological well-being: The mediating role of meaningful work. Journal of Occupational Health Psychology, 12(3), 193-203. http://dx.doi.org/10.1037/1076-8998.12.3.193

Avolio, B. J., Gardner, W. L., Walumbwa, F. O., Luthans, F., \& May, D. R. (2004). Unlocking the mask: A look atthe process by which authentic leaders impact follower attitudes and behaviors. The Leadership Quarterly, 15, 801-823. http://dx.doi.org/10.1016/j.leaqua.2004.09.003

Bandura, A. (1977). Self-efficacy: Toward a unifying theory of behavioral change. Psychological Review, 84, 191-215. http://dx.doi.org/10.1037/0033-295X.84.2.191

Bandura, A. (1982). Self-efficacy mechanism in human agency. American Psychologist, 37, 122-147. http://dx.doi.org/10.1037/0003-066X.37.2.122

Bandura, A. (1997). Self-efficacy: The exercise of control. New York: Freeman.

Bass, B. M. (1985). Leadership: Good, better, best. Organizational Dynamics, 13, 26-40.

Bass, B. M. (1998). Transformational leadership: Industrial, military and educational impact. Mahwah, NJ: Lawrence Erlbaum. http://dx.doi.org/10.1016/0090-2616(85)90028-2

Bass, B. M., \& Avolio, B. J. (1990). Multifactor leadership development: Manual for the multifactor leadership questionnaire. Palo Alto, CA: Consulting Psychologist Press.

Bass, B. M., \& Riggio, R. E. (2006). Transformational leadership. Lawrence Erlbaum, Mahwah, NJ.

Bhupinder, S., \& Rakhi, U. (2009). Self-efficacy and well-being of adolescents. Journal of the Indian Academy of Applied Psychology, 35(2), 227-232.

Bisschop, M. I., Knegsman, D. M. W., Beekman, A. T. F., \& Deeg, D. J. H. (2004). Chronic diseases and depression: The modifying role of psychosocial resources. Social Science and Medicine, 59, 721-733. http://dx.doi.org/10.1016/j.socscimed.2003.11.038

Bono, J. E., \& Ilies, R. (2006). Charisma, positive emotions and mood contagion. The Leadership Quarterly, 17, 317-334. http://dx.doi.org/10.1016/j.leaqua.2006.04.008

Cervone, D., \& Peake, P. K. (1986). Anchoring, efficacy, and action: The influence of judgmental heuristics on self-efficacy judgments and behavior. Journal of Personality and Social Psychology, 50, 492-501. http://dx.doi.org/10.1037/0022-3514.50.3.492

Collins, A. L. (2006). Subjective well-being in old age: An investigation into the role of flow and creativity. Dissertation, Boston College.

Danna, K., \& Griffin, R. W. (1999). Health and well-being in the workplace: A review and synthesis of the literature. Journal of Management, 25, 357-384. http://dx.doi.org/10.1177/014920639902500305

Datu, J. A. (2013). Be happy and believe in your capacity: Establishing link between subjective well-being and self-efficacy among Filipino adolescents. International Journal of Research Studies in Psychology, 2(3), 3-10. http://dx.doi.org/10.5861/ijrsp.2012.206

Diener, E. (2000). Subjective well-being. The science of happiness and a proposal for a national index. American Psychologist, 55(1), 34-43. http://dx.doi.org/10.1037/0003-066X.55.1.34

Diener, E., Emmons, R. J., Larsen, R. J., \& Griffin, S. (1985).The satisfaction with life scale. Journal of Personality Assessment, 49(1), 71-75. http://dx.doi.org/10.1207/s15327752jpa4901_13

Dolan, B. P., \& Metcalfe, R. (2012). The relationship between innovation and subjective wellbeing. Research Policy, 41(8), 1489-1498. http://dx.doi.org/10.1016/j.respol.2012.04.001

Eid, M., \& Larson, R. J. (2008). The science of subjective well-being. New York: Guilford Press.

Farmer, S. M., Tierney, P., \& Kung-Mcintyre, K. (2003). Employee creativity in Taiwan: An application of role identity theory. Academy of Management Journal, 46(5), 618-630. http://dx.doi.org/10.2307/30040653

Gilbreath, B., \& Benson, P. G. (2004). The contribution of supervisor behaviour to employee psychological well-being. Work \& Stress, 18(3), 255-266. http://dx.doi.org/10.1080/02678370412331317499

Gist, M. E., \& Mitchell, T. R. (1992). Self-efficacy: A theoretical analysis of its determinants and malleability. 
Öcel, H.

Academy of Management Review, 17, 183-211.

Gong, Y., Huang, J. C., \& Farh, J. L. (2009). Employee learning orientation, transformational leadership, and employee creativity: The mediating role of employee creative self-efficacy. Academy of Management Journal, 52(4), 765-778. http://dx.doi.org/10.5465/AMJ.2009.43670890

Greaves, C. J., \& Farbus, L. (2006). Effects of creative and social activity on the health and well-being of socially isolated older people: outcomes from a multi-method observational study. Public, Environmental \& Occupational Health, 126(3), 134-142. http://dx.doi.org/10.1177/1466424006064303

Harris, K. J., \& Kacmar, K. M. (2006). Too much of a good thing: The curvilinear effect of leader-member exchange on stress. The Journal of Social Psychology, 146(1), 65-84. http://dx.doi.org/10.3200/SOCP.146.1.65-84

House, J. S. (1981). Work stress and social support. Reading, MA: Addison Wesley.

Jöreskog, K., \& Sörbom, D. (2001). Structural equation modeling with the SIMPLIS command language. Hillsdale, NJ: Lawrence Erlbaum Associates.

Judge, T. A, \& Bono, J. E. (2000). Five-factor model of personality and transformational leadership. Journal of Applied Psychology, 85, 751-765. http://dx.doi.org/10.1037/0021-9010.85.5.751

Kark, R., Shamir, B., \& Chen, G. (2003). The two faces of transformational leadership: Dependence and empowerment. Journal of Applied Psychology, 88, 243-255. http://dx.doi.org/10.1037/0021-9010.88.2.246

Kelloway, E. K., Turner, N., Barling, J., \& Loughlina, C. (2012).Transformational leadership and employee psychological well-being: The mediating role of employee trust in leadership. Work \& Stress, 26(1), 39-55. http://dx.doi.org/10.1080/02678373.2012.660774

Liu, J., Siu, O.-L., \& Shi, K. (2010). Transformational leadership and employee well-being: The mediating role of trust in the leader and self-efficacy. Applied Psychology, 59(3), 454-479. http://dx.doi.org/10.1111/j.1464-0597.2009.00407.x

Liu, W., Zhu, R., \& Yang, Y. (2010). I warn you because I like you: Voice behavior, employee identifications, and transformational leadership. The Leadership Quarterly, 21(1), 189-202. http://dx.doi.org/10.1016/j.leaqua.2009.10.014

McLellan, R., Galton, M., Steward, S., \& Page, C. (2012). The impact of creative initiatives on wellbeing: A literature review. Creative, Culture and Education Series. Newcastle, England: Creativity, Culture and Education.

Nielsen, K., \& Daniels, K. (2012). Does shared and differentiated transformational leadership predict followers' working conditions and well-being? The Leadership Quarterly, 23, 383-397. http://dx.doi.org/10.1016/j.leaqua.2011.09.001

Nielsen, K., \& Munir, F. (2009). How do transformational leaders influence followers' affective well-being? Exploring the mediating role of self-efficacy. Work \& Stress, 23(4), 313-329. http://dx.doi.org/10.1080/02678370903385106

Nielsen, K., Randall, R., Yarker, J., \& Brenner, S.-O. (2008). The effects of transformational leadership on followers' perceived work characteristics and psychological wellbeing: A longitudinal study. Work \& Stress, 22, 16-32. http://dx.doi.org/10.1080/02678370801979430

Offermann, L. R., \& Hellmann, P. S. (1996). Leadership behavior and subordinate stress: A $360^{\circ}$ view. Journal of Occupational Health Psychology, 1, 382-390. http://dx.doi.org/10.1037/1076-8998.1.4.382

Pavot, W., Diener, E., Colvin, C. R., \& Sandvik, E. (1991). Further validation of the satisfaction with life scale: Evidence for the cross-method convergence of well-being measures. Journal of Personality Assessment, 57, 149-161. http://dx.doi.org/10.1207/s15327752jpa5701_17

Podsakoff, P. M., MacKenzie, S. B., Lee, J. Y., \& Podsakoff, N. P. (2003). Common method biases in behavior research: a critical review of the literature and recommended remedies. Journal of Applied Psychology, 88(5), 879-903. http://dx.doi.org/10.1037/0021-9010.88.5.879

Priesack, A., \& Alcock, J. (2015). Well-being and self-efficacy in a sample of undergraduate nurse students: A small survey study. Nurse Education Today, 35(5), 16-20. http://dx.doi.org/10.1016/j.nedt.2015.01.022

Ryff, C. D. (1995). Psychological well-being in adult life. Current Directions in Psychological Science, 4(4), 
How does creative self-efficacy influence employee well-being? Moderating role of transformational leadership

99-104. http://dx.doi.org/10.1111/1467-8721.ep10772395

Shin, S. J., \& Zhou, J. (2003). Transformational leadership, conservation, and creativity: Evidence from Korea. The Academy of Management Journal, 46, 703-714. http://dx.doi.org/10.2307/30040662

Singh, B., \&, Tung, N. S. (2015). The relationship between relativity and psychological distress. International Journal of Science and Research, 4(6), 931-934.

Siu, O., Lu, C., \& Spector, P. E. (2007). Employees' well-being in greater China: The direct and moderating effects of general self-efficacy. Applied Psychology: An International Review, 56(2), 288-301. http://dx.doi.org/10.1111/j.1464-0597.2006.00255.x

Sivanathan, N., Arnold, K. A., Turner, N., \& Barling, J. (2004). Leading well: Transformational leadership and well-being. In P. A. Linley \& S. Joseph (Eds.), Positive psychology in practice (pp. 241-255). New York: Wiley. http://dx.doi.org/10.1002/9780470939338.ch15

Skakon, J., Nielsen, K., Borg, V., \& Guzman, J. (2010). Are leaders' well-being, behaviours and style associated with the affective well-being of their employees? A systematic review of three decades of research. Work \& Stress, 24(2), 107-139. http://dx.doi.org/10.1080/02678373.2010.495262

Sosik, J. J., \& Godshalk, V. M. (2000). Leadership, mentoring functions received, and job-related stress: A conceptual model and preliminary study. Journal of Organizational Behavior, 21, 365-390. http://dx.doi.org/10.1002/(SICI)1099-1379(200006)21:4<365::AID-JOB14>3.0.CO;2-H

Souza, L. A. S., Torres, A. R. R., Barbosa, G. A., Lima, T. J. S., \& Souza, L. E. C. (2014). Self-efficacy as a mediator of the relationship between subjective well-being and general health of military cadets. $\mathrm{Cad}$. Saúde Pública, 30(11), 2309-2319. http://dx.doi.org/10.1590/0102-311X00177513

Sparks, K., Faragher, B., \& Cooper, C.L. (2001). Well-being and occupational health in the 21st century workplace. Journal of Occupational and Organizational Psychology, 74(4), 489-509. http://dx.doi.org/10.1348/096317901167497

Stenling, A., \& Tafvelin, S. (2014).Transformational leadership and well-being in sports: The mediating role of need satisfaction. Journal of Applied Sport Psychology, 26, 182-196. http://dx.doi.org/10.1080/10413200.2013.819392

Tamannaeifar, M. R., \& Motaghedifard, M. (2014). Subjective well-being and its sub-scales among students: The study of role of creativity and self-efficacy. Thinking Skills and Creativity, 12, 37-42. http://dx.doi.org/10.1016/j.tsc.2013.12.003

Tierney, P., \& Farmer, S. M. (2002). Creative self-efficacy: Its potential antecedents relationship to creative performance. Academy of Management Journal, 45(6), 1137-1148. http://dx.doi.org/10.2307/3069429

Tierney, P., \& Farmer, S. M. (2011). Creative self-efficacy development and creative performance over time. Journal of Applied Psychology, 96(2), 277-293. http://dx.doi.org/10.1037/a0020952

van Dierendonck, D., Haynes, C., Borrill, C., \& Stride, C.(2004). Leadership behavior and subordinate well-being. Journal of Occupational Health Psychology, 9(2), 165-175. http://dx.doi.org/10.1037/1076-8998.9.2.165

Wright, T. A., \& Staw, B. M. (1999). Affect and favorable work outcomes: Two longitudinal tests of the happy-productive worker thesis. Journal of Organizational Behavior, 20(1), 1-23. http://dx.doi.org/10.1002/(SICI)1099-1379(199901)20:1<1::AID-JOB885>3.0.CO;2-W

Yetim, Ü. (1993). Life satisfaction: A study based on the organization of personal projects. Social Indicator Research, 29, 277-289. http://dx.doi.org/10.1007/BF01079516

Zhu, W., Newman, A., Miao, Q., \& Hooke, A. (2013). Revisiting the mediating role of trust in transformational leadership effects: Do different types of trust make a difference? The Leadership Quarterly, 24, 94-105. http://dx.doi.org/10.1016/j.leaqua.2012.08.004 
Öcel, H. 